\title{
Principal's Management Competencies in Improving the Quality of Education
}

\author{
Komalasari \\ SD Negeri 1 Lais \\ e-mail: komalasarisyaipul@gmail.com \\ Yasir Arafat \\ Universitas PGRI Palembang \\ e-mail: yasir_arafat14@yahoo.com \\ Mulyadi \\ Universitas PGRI Palembang \\ e-mail:mulyadi@univpgri-palembang.ac.id \\ Article History: Received on 1 October 2020, Revised on 11 October 2020, \\ Published on 14 October 2020
}

\begin{abstract}
This study determined the management competence of principals in improving the quality of education in SD Negeri 1 Epil, Lais District, Musi Banyuasin Regency. This research method is a qualitative descriptive. Sources of data in this study were teachers who assisted in the learning process at SD Negeri 1 Epil, Lais District, Musi Banyuasin Regency. Data collection techniques in this study include 1) interviews and 2) documentation. The data analysis used in this study were 1) data reduction, 2) display or presentation of data and 3) conclusions and data verification. The results showed that the management competence of the principal in improving the quality of education in Lais District was good. This paper contributes to upgrade the principal's management competence in order to improve the quality of education.
\end{abstract}

Keywords: Management Competence, Principal, Quality of Education

\section{A. Introduction}

The profession of the Principal is not as easy as it seems, especially when it comes to the current dynamics, including the latest trend, namely the demand for accountability. The principal faces greater challenges than the past in carrying out the duties and functions he plays on a daily basis. This occurs because of a higher hierarchy of authority and power than the group that supervises or auditors (Avoid and Black, 2014).

Other challenges faced by school principals in the future are quite numerous. These challenges include ensuring a sustainable quality learning process, integrating basic knowledge and skills in a balanced manner through the applied curriculum, managing the behavior and attendance of personnel in schools, managing resources and the environment strategically, building schools as learning community centers. who are professional, and develop partnerships and cooperation not limited to the context of the school but seek support from parents and the community to synchronize and develop learning innovation opportunities (Day and Sammons, 2014). 
Facing these dynamic challenges, the principal cannot move alone. As a component of the regional government authority, the support and commitment of the local government, including the education office at the provincial, district and city levels is an important requirement. Local government support and commitment should be considered as a long-term investment that will develop a more developed education sector. The investment involves time, energy, money and other relevant resources. In the view of Avoid and Black (2014) quoted by Hendarman (2018), this support is to change the perception and paradigm of current school principals who tend to be "alone". This is because the position often causes communication distance with other people, even in school circles where the position of the principal is considered a very special position. This loneliness causes school principals to often find it difficult to find solutions to the obstacles they face and to get quality feedback and guidance.

Principals in the "present age" play a more complex role that requires multitasking abilities and dynamic role changes. The leadership of the principal is effective and widely accepted as a key component for realizing school quality improvement. The quality of the school has an impact on the motivation of its staff and teacher performance in the quality of learning in class (Hartle and Thomas, 2013).

One important factor that influences the learning process in an educational unit or school is the presence of the principal. The existence of a school principal can change the face of the school for the better or for the worse over time. What are the characteristics of a good principal, so that it can affect the running of the existing system in schools? A good principal is expected to 1) shape the implementation of learning that is carried out by the teacher to be good; 2) can create conditions that allow the birth of a working climate and human relations that are harmonious and conducive; 3) can influence in determining organizational goals, motivate follower behavior to achieve goals, influence to improve the group and culture (Hendarman, 2018).

According to Mulyasa (2014) principals who succeed when they understand the existence of the school as a complex and unique organization, and are able to carry out the role of the principal as a supervisor who is given the responsibility to lead the school. The achievement of educational goals is highly dependent on the leadership skills and wisdom of the principal as a supervisor who is one of the education leaders.

It is emphasized by Marno (2018) who argues that the principal is a professional official in the school organization who is in charge of managing all organizational sources and collaborating with teachers in educating students to achieve educational goals. With the professionalism of the principal as a supervisor for the professional development of educational personnel, it is easy to do because in accordance with his function, the principal understands the needs of the school he leads so that the competence of teachers is not only in the competencies he had before, but increases and develops well so that teacher professionalism will be realized.

Professional education staff not only master the right fields of science, teaching materials, and methods, but are able to motivate students, have high skills and broad insight into the world of education. Professionalism of education personnel is also consistently one of the most important factors of education quality. Professional education personnel are able to teach students effectively according to resource and environmental constraints (Risdianto et 
al, 2020). However, to produce professional teachers is also not an easy task. Teachers must be more dynamic and creative in developing student learning processes. In order for the education process to run effectively and efficiently, teachers are required to have adequate competence, both in terms of type and content (Siagian, 2017).

Through principal management, a principal will be able to transfer several values such as emphasis on groups, support for teachers and employees, tolerance for risk, change criteria and so on on the other hand, employees will form a subjective perception of the basics of values that exist in the organization is in accordance with the values that the leader wants to convey through his leadership management (Hendarman, 2018).

To adjust between values, a process called socialization is needed. This process will work well if new employees will feel happy with the work environment they occupy. No different from teachers or students in a school, of course they will feel happy and the Teaching and Learning Process will run well. Principals are able to serve and carry out their functions well too. In an effort to maintain and improve employee performance, a leader who uses his role in carrying out tasks and has personal abilities is also able to read the conditions of his subordinates and their work environment. In this case, the maturity of subordinates is directly related to the right leadership to be applied so that the principal gets adequate obedience or influence. For this reason, the principal must be able to create a work atmosphere that is supported by his subordinates to always work professionally. Not misusing for personal gain, but to achieve individual goals in the organization so that subordinates' work performance can be improved and organizational goals can be achieved more effectively and efficiently (Suharsaputra, 2018).

A leader in a school who is finally called the Principal, in the context of the principal's duties is very heavy because he must be able to play multiple roles. Apart from being a leader, of course, they are able to become partners of teachers in teaching and educating their students. And of course every leader has his own way and method of carrying out his duties and functions (Sahertian, 2016).

Regarding the management of the principal, and the expectations a school is trying to achieve, the quality of education is the main goal that every school must fulfill. Therefore, in its implementation, it does not only require technical skills from experts to improve the quality of education, but must also understand the various factors that influence it (Supratikno, 2016).

According to Mulyasa (2013), there are several factors that make a leader improve the quality of education. First, the leader meets the needs of his subordinates with regard to the effectiveness of the job. Second, leaders provide the training, guidance and support their employees need. In an effort to increase the professionalism of subordinates, the role of leadership is very important, because the success or failure of a goal achieved by an organizational institution depends on its leadership. And this is an obligation for each leader to be able to lead his subordinates so that they can work in accordance with the instructions given so that it will create working conditions and environments that encourage work activities to achieve organizational goals effectively and efficiently.

The low quality of learning can be caused by several factors, as stated by Mulyasa (2013) explaining that there are seven main problems of national education, namely: decreased 
morals and morals of students, equal learning opportunities, low internal efficiency of the education system, institutional status, management. education that is not in line with national development and unprofessional resources.

The condition of educational institutions in our country today still has some classic problems, namely the lack of school infrastructure, the condition of the buildings that are damaged, the quality of the teaching staff has not met the competence and policies are less productive. On the other hand, it is very encouraging, namely that public awareness is increasing on the importance of quality education (Nanang, 2016).

In this regard, educational goals can be achieved if all components of education meet the requirements. Of the several components of education, the most important role is the principal. A quality school principal will be able to answer the challenges of changing times that are increasingly fast. In the future, educational problems will become more complex, requiring school principals to always make various efforts to improve the competence of all school components (Wahjosumidjo, 2016).

Leadership has a very significant role in improving the quality of education in schools. According to Karwati (2016), leadership is the ability to have a constructive influence on others to make a cooperative effort to achieve planned goals. Based on this definition, there are three important elements in the leadership process (1) the ability to influence others or the process to influence others, (2) the presence of other people who are influenced, and (3) the existence of certain goals to be achieved.

Quality education is produced by quality school principal management, quality school principals are professionals. Professional school principals are capable of managing and developing schools comprehensively (as a whole), therefore the principal has a very important and strategic role in realizing the vision, mission and goals of the school. Professional school principals in carrying out their duties are full of quality improvement strategies, so as to produce quality outputs and outcomes. Good management of school principals will show the quality of education in schools (Purwanto, 2014).

The achievement of the goals of school educational institutions is very dependent on the skills and leadership policies of the principal as an educational leader. The principal is a professional official in managing the school organization as well as being in charge of regulating and managing all sources, organizations and in collaboration with community school committees, other institutions and existing stakeholders. The leadership of the principal in developing and managing the school must understand the needs of the school he leads, including the needs of teachers, students and school members. Professional school principals will always motivate all school components to increase their competence so that the competence of school residents can increase and develop well. Principals and teachers as professional educational staff not only master the fields of science, teaching materials, and methods, but are able to motivate students to have broad skills and insights into education (Rohiat, 2013).

Many factors inhibit the achievement of the quality of school principal management when viewed from the low performance of the principal. Based on empirical experience, it shows that the average principal lacks academic ability, lacks self-motivation, lacks enthusiasm and work discipline, and has narrow educational insights. This phenomenon is caused by the lack 
of competency, procedural, lack of transparency, lots of nuances/content, not competitiveness and internal and external factors of school principals that can hinder their growth and development to become professional school principals. Low professionalism has an impact on the low productivity of school principals in improving the quality of education (Hendarman, 2018).

A quality school is an educational institution that builds people's trust in choosing this educational institution as a place to study for their children. Therefore, every educational institution is required to always improve the quality of its education. Because referring to the Government Regulation of the Republic of Indonesia Number 19 Year 2005 National Education Standards, Article 91 Paragraph 1 and 2 states that: "Every education unit in the formal and non-formal channels is obliged to guarantee the quality of education. Education quality assurance as referred to in subsection (1) aims to meet or exceed the National Education Standards. " Referring to the Regulation of the Minister of National Education of the Republic of Indonesia Number 13 of 2007 concerning the Standards for Principals of Schools or Madrasahs, the principal must be at least able to function as educators, managers, administrators, supervisors, leaders, innovators, motivators and entrepreneurs (Danim, 2010).

Thus schools which are formal educational institutions are directed to improve the quality of education. According to Nata, what is meant by the quality of education is education which all components and various other supporting tools can satisfy students, leaders, teachers and society in general. This quality component is related to the curriculum or lessons given, the teaching and learning process, teaching staff, facilities and infrastructure, environment, management (Nata, 2013).

Quality problems in an educational institution are the most serious problems. On average, there are still many educational institutions that have not succeeded in realizing the quality of education. In fact, the quality of education is the common goal of all educational thinkers and practitioners, and it has even been pursued through various means, methods, approaches, strategies and policies (Hidayat and Asroi, 2013).

But in reality, currently some schools in Lais Subdistrict, Musi Banyuasin Regency are still experiencing poor quality of education. Some schools of education quality are still low, this condition can be assessed in terms of infrastructure, curriculum, programs, media and tools to support readiness in achieving quality education. If the infrastructure, curriculum, programs, media and supporting tools are not fulfilled, the quality of education in several primary or secondary education institutions is still low. So that it will affect the difficulty of acquiring new students in the new academic year.

The results of preliminary observations by researchers at SD Negeri 1 Epil, Lais District, Musi Banyuasin Regency, obtained information that the learning process was carried out in the morning starting from 07.00 WIB to $12.15 \mathrm{WIB}$, and extracurricular activities were carried out at 14.30 WIB until 17.00 WIB . The vision of SD Negeri 1 Epil, Lais Subdistrict, Musi Banyuasin Regency is: "Forming Intelligent, Creative, Social and Godly People". The school's mission is: 1) To form students into a generation who are faithful and pious; 2) Creating an active, creative and quality teaching and learning environment; 3) Excellent in science and technology, sports and arts; 4) Guiding students in religious and yasinan activities; 5) SukA Helping friends in all kindness; 6) Guiding students in activities caring for the beauty of the environment. The school objectives are: 1) Increase student passing scores; 
2) Winning science, sports and arts competitions; 3) Increasing devotion to God Almighty (Carrying out Yasinan activities together); 4) Creating students who are social; 6) Creating students who can use the environment to become a source of life.

There are 15 teachers and 264 students at SD Negeri 1 Epil, Lais District, Musi Banyuasin Regency. The facilities and infrastructure of SD Negeri 1 Epil, Lais District, Musi Banyuasin Regency have 10 classrooms, 7 classrooms in good condition, and 3 classrooms in damaged condition. Besides that, there are also supporting facilities such as library rooms, teacher rooms, warehouses, male student toilets and female students' toilets, male teacher toilets and female teacher toilets. SD Negeri 1 Epil, Lais Subdistrict, Musi Banyuasin Regency is currently accredited "B".

Seeing this situation, the researcher wanted to conduct a research study on the management ability of school principals in improving the quality of education at SD Negeri 1 Epil, Lais District through a study entitled: "Principal Management Competence in Improving the Quality of Education in Lais District". The hope of researchers through this research can contribute to how management should be carried out by the principal as a leader in an effort to improve the quality of education in SD Negeri 1 Epil, Lais District, Musi Banyuasin Regency. Besides that, the reason for the researchers conducting this research study was strengthened by relevant research studies such as that carried out by Jafar (2018) in his research journal entitled: "Principal Managerial Competence in Improving Teacher Performance at Al-Fityan Integrated Islamic Junior High School, Aceh Besar District". And research conducted by Rosita (2016) in her research journal entitled: "The Principal's Efforts to Improve the Quality of Islamic Education (Case Study at MTs Al-Inayah Bandung)". Through this relevant research study, it provides inspiration for researchers to carry out this research study, hopefully through the reference of this relevant research study it can contribute to the principal in improving the quality of education in SD Negeri 1 Epil, Lais District, Musi Banyuasin Regency.

\section{B. Methods}

This research method is a qualitative descriptive method. Qualitative methods are used to analyze data in the form of information, such as the results of observations, documentation, using two ways of thinking, namely as follows. 1) Deductive thinking, namely a way of thinking that departs from general knowledge and is based on general knowledge that wants to assess a specific activity; and 2) Inductive thinking, which is a way of thinking that departs from specific facts, concrete events, then general generalizations are drawn from those concrete facts (Hadi, 2011). Thus, this study refers to direct observations made by researchers in collecting research data, so that the data and the validity of the research are truly valid to be used as research. Sources of data in this study were teachers who assisted in the learning process at SDN 1 Epil, Lais District, Musi Banyuasin District in order to determine the competence of school principal management in improving the quality of education and other supporting data related to this research, for example research permits, research photos.

Data collection techniques in this study include: 1) interviews or interviews and 2) documentation. The research instrument referred to in this study was an interview instrument aimed at the principal of SDN 1 Epil, Lais District, Musi Banyuasin Regency. Qualitative data analysis used in this study as stated by Sugiyono (2015) uses three stages: 1) data reduction, 2) data display or presentation and 3) conclusion and data verification. 


\section{Results and Discussion}

Based on the results of the research, it is known that the management competence of the principal in improving the quality of education in Lais District is already good in managing the school as an educational institution, the principal in formulating a vision is very good and it is really determined. The mission of the school is carried out in accordance with the hope that this school will truly become a school capable of producing proud quality graduates. In addition, the principal in carrying out his duties to achieve school goals carries out achievement strategies, such as sending teachers to participate in training activities, seminars and so on. However, given the current pandemic condition, activities like this were eliminated, both from the Musi Banyuasin Education Office itself and from the Provincial Education Office.

The Principal in organizing the school has designed and made an Organizational Structure as a reference so that staff can carry out their duties according to their respective functions, the Principal in providing motivation to staff in administrative management and providing directions in the administration of correspondence is good. The school principal in providing supervision, controlling the work of school staff and residents as well as providing guidance so that the work implementation process runs even better. Judging from conducting evaluations every mid-semester to find out the learning outcomes that have been achieved by students, the principal is able to direct it to teachers.

In addition, the Principal tries to solve existing problems and tries to minimize and eliminate problems if there are any in a wise way. The management competence of the principal in improving the quality of education in Lais District is already good by trying to solve problems in the school creatively and overcoming existing problems. The school principal has provided directions long before the process of making learning tools. The competence of school principal management in improving the quality of education in Lais District is good in terms of providing directions to teachers to make learning tools that must refer to the established curriculum. The competence of school principal management in improving the quality of education in Lais District has been good in terms of providing directions to teachers in planning for chasing.

The principal in providing guidance to teachers in carrying out learning so that it refers to the curriculum (Wachidi 2019; Hamzah et al, 2020). The management competence of the principal in improving the quality of education in Lais Subdistrict is good in that the principal asks teachers to provide reports on student learning outcomes every quarter or mid-semester on the learning outcomes that students have obtained. The management competence of the principal in improving the quality of education in Lais District has been good for the results achieved by students in the learning process every semester requested by the Principal.

Judging from the direction of the principal who asks overall the results of student achievement both during mid-semester, semester and at the end of the year, but only asks for value graph data as a report and directs teachers to follow up on deficiencies in the learning process that has been achieved by provide remedials to students who score below the KKM standard. The management competence of the principal in improving the quality of education in Lais Subdistrict is already good, the principal always fosters teachers so that the learning process is given to students later in accordance with the set curriculum. The principal has provided guidance to teachers to pay attention to students who have difficulty learning. The 
competence of school principal management in improving the quality of education in Lais District is already good, in the current state of the Covid 19 pandemic, education and training activities are eliminated, but if there are training activities, the Principal will send appointed teachers to participate in them.

To improve the quality of education at SD Negeri 1 Epil requires a very long process, this is due to the replacement of the principal and the lack of existing infrastructure. In 2012 SD Negeri 1 Epil received the accreditation predicate "B" with a score of 72. In 2017 SD Negeri 1 Epil received the accreditation predicate "B" with a score of 84 .

Based on theoretical studies, the profession of the Principal is not as easy as imagined, especially when it comes to the dynamics occurring including the latest trends, namely the demand for accountability. The principal faces greater challenges than the past in carrying out the duties and functions he plays on a daily basis. This occurs because of a higher hierarchy of authority and power than the group that supervises or auditors (Avoid and Black, 2014).

Facing these dynamic challenges, the principal cannot move alone. As a component of the regional government authority, the support and commitment of the local government, including the education office at the provincial, district and city levels is an important requirement. Local government support and commitment should be considered as a long-term investment that will develop a more developed education sector. The investment involves time, energy, money and other relevant resources. In the view of Avoid and Black (2014) quoted by Hendarman (2018), this support is to change the perception and paradigm of current school principals who tend to be "alone". This is because the position often causes communication distance with other people, even in school circles where the position of the principal is considered a very special position. This loneliness causes school principals to often find it difficult to find solutions to the obstacles they face and to get quality feedback and guidance.

One important factor that influences the learning process in an educational unit or school is the presence of the principal. The existence of a school principal can change the face of the school for the better or for the worse over time. What are the characteristics of a good principal, so that it can affect the running of the existing system in schools? A good principal is expected to: 1) shape the implementation of learning that is carried out by the teacher to be good; 2) can create conditions that allow the birth of a working climate and human relations that are harmonious and conducive; 3) can influence in determining organizational goals, motivate follower behavior to achieve goals, influence to improve the group and culture (Hendarman, 2018).

Through the management of the school principal, a principal will be able to transfer several values such as emphasis on groups, support for teachers and employees, tolerance for risk, change criteria and so on. On the other hand, employees will form a subjective perception of the basics of values that exist in organization in accordance with the values that the leadership wants to convey through their leadership management (Hendarman, 2018).

To adjust between values, a process called socialization is needed, this process will work well if new employees will feel happy with the work environment they occupy. No different from teachers or students in a school, of course they will feel happy and the Teaching and Learning Process will run well. Principals are able to serve and carry out their functions well too. In an 
effort to maintain and improve employee performance, a leader who uses his role in carrying out tasks and has personal abilities is also able to read the conditions of his subordinates and their work environment. In this case, the maturity of subordinates is directly related to the right leadership to be applied so that the principal gets adequate obedience or influence. For this reason, the principal must be able to create a work atmosphere that is supported by his subordinates to always work professionally. Not misusing for personal gain, but to achieve individual goals in the organization so that subordinates' work performance can be improved and organizational goals can be achieved more effectively and efficiently (Suharsaputra, 2018).

Based on the results of the research obtained, the relevant research conducted by Hari (2016), the results of his research concluded: 1) Improving the quality of learning at SD Muhamadiyah Wonorejo is determined how the principal can manage school management and the ability to determine the vision, mission, and educational objectives of SD Muhammadiyah Wonorejo. Strategies and targets according to the situation and conditions of the school; 2) Improving the quality of the principal's leadership competence in carrying out its duties and functions is very much determined by the principal's self-motivation and how to manage learning input, carry out the learning process, and produce learning output; 3) Overall the condition of the Principal of SD Muhamadiyah Wonorejo in carrying out its duties and functions as educator, manager, administrator, supervisor, leader, innovator, motivator is very good so that the principal can be an example in running his job. This study has similarities and differences with the current research, which both examines the principal and the quality of education. Furthermore, the difference that exists in this study with current research is that the place is used as research, helping to contribute to the achievement of this research result (Zulaiha at al, 2020; Listiningrum et al, 2020).

Furthermore, research conducted by Khazanah (2017) shows that the efforts of the principal in improving the quality of education at Darussalam SMP are seen in the indicators of input, process, and output. As for the efforts of the principal in improving the quality of education in relation to the input indicator, it is preparing professional educators; both through coaching; discussions and meetings; academic seminars; includes training, workshops; and training, refining student recruitment strategies through promotions. The efforts of the head of SMP Darussalam in improving the quality of education in terms of process indicators are to condition a safe learning environment; comfortable; and stimulate learning, making programs according to student needs including; memorizing Quran; mentoring reading Quran; worship formation; extracurricular activities, provide motivation to learn; both giving rewards and punishments to teachers and students. The effort of the head of SMP Darussalam in improving the quality of education in relation to output indicators, is trying to excel in academics and non-academics. This study has similarities and differences with the current research, which both examines the principal and the quality of education. Furthermore, the difference that exists in this study and the current research is that the place used for research also helps the results achieved in this study.

Fitria (2019), the results of showed that 14 items do not meet the standards contained in Permen 24/2007, infrastructure that does not meet the standards, namely: Classrooms, library rooms, biology laboratory rooms, physics laboratory rooms, chemistry laboratory rooms, computer laboratory room, language laboratory room, teacher room, UKS room, student organization room, latrines, warehouse, circulation room, and sports equipment room. Meanwhile, there are only 4 items in accordance with the standards contained in Permen 
Volume 1 (2) 2020

E-ISSN: 2723-6919 P-ISSN:2746-0827

24/2007, namely: the leadership room, administration room, prayer room, and counseling room. The principal as the head of the school has implemented an administrative function to fix the existing infrastructure in the school starting from the planning, coordinating, distribution, to accountability functions, by setting these functions it is hoped that these functions can optimize infrastructure in improving the learning process at SMA Negeri 9 Palembang. From this relevant research, the researcher concludes that there are similarities and differences between the research and current research, namely both researching teacher management in the learning process, then the differences in this study and current research are the research places and subject studies that are the focus of research.

Research by Tobari et al (2018) found that "the strategy was undertaken by the Headmaster of SMK Negeri 1 Bukittinggi in order to improve the quality of education dealing with the AEC is improving the competence and qualifications of teachers". Then the strategy from Headmaster of SMK PGRI Tanjung Raja is training maximally the students. Last the Headmaster of SMK Negeri 1 Pangkalan Kuras was equip the needs of the building, laboratory, and equipment gradually. Increasing MoU with companies for sharing technology. Improving MoU with higher education institutions for knowledge sharing. Increasing availability of library books to support effective learning. Based on the relevant research, an equation was found, namely both researching the principal. While the difference lies in the place of research and the study of the subject which is the focus of the research.

\section{Conclusion}

Based on the results of the study, it can be concluded that the management competence of principals in improving the quality of education in Lais District is good. Principals in the "present age" play a more complex role that requires multitasking abilities and dynamic role changes. The leadership of the principal is effective and widely accepted as a key component for realizing school quality improvement. The quality of the school has an impact on the motivation of its staff and teacher performance in the quality of learning in the classroom.

\section{E. Acknowledgement}

We thank to the principal of SD Negeri 1 Lais, Rector Universitas PGRI Palembang who gave us the support to do this wonderful project. This project was funded independent. We would also like to thank our friends in Educational Management who helped us a lot in finalizing this project within the limited time frame.

\section{References}

Avoid L., \& Black W. L. (2014). The Changing Role of the Principal (How-Hight-Achieving Districs are Recalibratingm School LeardershipI. Centre for American Progress: www.americanprogras.org.

Danim, S., \& Khairil. (2010). Profesi Kependidikan [Educational Profession]. Bandung: Alfabeta.

Day, C., \& Sammons, P. (2014). Successful School Leadership. The University of Notthingham: Education Development Trust. 
Fitria, H. (2019). Manajemen Sarana Prasarana dalam Meningkatkan Proses Pembelajaran [Infrastructure Management in Improving the Learning Process]. Prosiding Seminar Nasional Pendidikan Program Pascasarjana Universitas PGRI Palembang 12 January 2019.

Hadi, S. (2011). Penelitian Kualitatif [Qualitative Research]. Bandung: Alfabeta.

Hamzah, S., Yussof, M. H. B., \& Enriquez, A. A. (2020). Togetherness in the Diversity of the Pancasila Ideology Frame. Journal of Social Work and Science Education, 1(1), 8-12. Retrieved from http://ejournal.karinosseff.org/index.php/jswse/article/view/5

Hari, M. (2016). Pengaruh Kepemimpinan Kepala Sekolah dalam Meningkatkan Mutu Pendidikan Sekolah (Studi tentang Manajemen Kepala Sekolah di SD Muhammadiyah Wonorejo Polokarto) [The Effect of Principal Leadership in Improving the Quality of School Education (Study of Principal Management at SD Muhammadiyah Wonorejo Polokarto)]. Jurnal Manajemen Pendidikan 1(3).

Hartle, F., dan Thomas, K. (2013). Growing Tomorrorw's School Leaders: The Challenge. Standford, California: the Haygroup.

Hendarman., \& Rohanim. (2018). Kepala Sekolah Sebagai Manajer Teori dan Praktik [Principal as Manager of Theory and Practice]. Bandung: Remaja Rosdakarya.

Hidayat, S., \& Asroi. (2013). Manajemen Pendidikan [Education Management]. Tangerang: Pustaka Mandiri.

Karwati, E. (2016). Kinerja dan Profesionalisme Kepala Sekolah Membangun Sekolah yang Bermutu [Performance and Professionalism of Principals to Build Quality Schools]. Bandung: Alfabeta.

Khazanah, N. (2017). Upaya Kepala Sekolah dalam Meningkatkan Mutu Pendidikan di SMP Darussalam Surakarta Tahun Pelajaran 2016/2017 [The Principal's Efforts to Improve the Quality of Education at SMP Darussalam Surakarta in the 2016/2017 Academic Year]. Jurnal Manajemen Pendidikan, 2(3).

Listiningrum, H. D., Wisetsri, W., \& Boussanlegue, T. (2020). Principal's Entrepreneurship Competence in Improving Teacher's Entrepreneurial Skill in High Schools. Journal of Social Work and Science Education, 1(1), 87-95. Retrieved from http://ejournal.karinosseff.org/index.php/jswse/article/view/20

Marno., \& Supriyatno, T. (2018). Manajemen dan Kepemimpinan [Management and Leadership]. Bandung: Reika Aditama.

Mulyasa, E. (2013). Manajemen dan Kepemimpinan Kepala Sekolah [Principal Management and Leadership]. Jakarta: Bumi Aksara.

Mulyasa, E. (2014). Menjadi Kepala Sekolah Profesional [Become a Professional School Principal]. Bandung: Remaja Rosdakarya. 
Nanang. (2016). Strategi Pendidikan [Educational Strategy]. Jakarta: Raja Graffindo Persada.

Nata, A. (2012). Kapita Selekta Pendidikan Islam: Isu-Isu Kontemporer tentang Pendidikan Islam [Capita Selekta of Islamic Education: Contemporary Issues on Islamic Education]. Jakarta: Raja Grafindo Persada.

Purwanto, N. (2014). Administrasi dan Supervisi Pendidikan [Education Administration and Supervision]. Jakarta: Rineka Cipta.

Risdianto, E., Fitria, J., Johan, H., \& Macariola, J. S. (2020). Teacher's Perception of Thermodynamic Law Module Developed in Training through Student's Critical Thinking Skills. Journal of Social Work and Science Education, 1(1), 78-86. Retrieved from http://ejournal.karinosseff.org/index.php/jswse/article/view/19

Rohiat. (2013). Kecerdasan Kepemimpinan Kepala Sekolah [Principal's Leadership Intelligence]. Bandung: Refika Aditama.

Sahertian, R. (2016). Supervisi Kepala Sekolah [Supervision of the Principal]. Jakarta: Rajawali Pers.

Siagian. (2017). Teori dan Praktek Kepemimpinan [Leadership Theory and Practice]. Jakarta: Rineka Cipta.

Sugiyono. (2015). Metode Penelitian Pendidikan, Pendekatan Kuantitatif, Kualitatif dan $R$ \& $D$ [Educational Research Methods, Quantitative Approaches, Qualitative and $R \&$ D]. Bandung: Alfabeta.

Suharsaputra. (2018). Supervisi Pendidikan (Pendekatan Sistem Berbasis Kinerja) [Education Supervision (Performance-Based Systems Approach)]. Bandung: Refika Aditama.

Supratikno, H. (2016). Manajemen Kinerja Untuk Menciptakan Keunggulan Bersaing [Performance Management To Create Competitive Advantage]. Yogyakarta: Graha Ilmu.

Tobari., Kristiawan, M. \& Asvio N. (2018). The strategy of Headmaster on Upgrading Educational Quality in Asean Economic Community (AEC) Era. International Journal of Scientific \& Technology Research 7 (4).

Wachidi, W. (2019). Teachers' Stage of Concern in Implementing of Elementary School Curriculum Innovation. International Journal of Educational Review, 1(2), 27-34.

Wahjosumidjo. 2015. Organisasi, Kepemimpinan \& Prilaku Administrasi [Organization, Leadership \& Administrative Behavior]. Jakarta: Gunung Agung.

Zulaiha, D., Lian, B., \& Mulyadi, M. (2020). The Effect of Principal's Competence and Community Participation on the Quality of Educational Services. Journal of Social 
Journal of Social Work and Science Education

Volume 1 (2) 2020

E-ISSN: 2723-6919 P-ISSN:2746-0827

Work and Science Education, 1(1), 45-57. Retrieved from http://ejournal.karinosseff.org/index.php/jswse/article/view/9 